\title{
Learning Organizations di Lingkungan Perusahaan Kecil-Menengah: Studi Empiris Wirausaha Mebel Rotan Di Sentra Industri Kecil Mebel Rotan Trangsan, Gatak, Sukoharjo
}

\author{
Sri Walyoto \\ Sekolah Tinggi Agama Islam Negeri Surakarta \\ sriwalyoto@yahoo.com
}

Setiap organisasi dituntut beradaptasi dan bertransformasi menjadi learning organizations, yaitu berupaya menjadikan dirinya sebuah organisasi yang mampu belajar. Berdasarkan model Analitical Hierarchy Process, terdapat kecenderungan di kalangan pekerja menempatkan aspek belajar dalam tim, sebagai prioritas terpenting sebagai piranti pembelajaran dan menempatkan kebebasan menyampaikan pendapat/ide, sebagai aspek yang kurang penting. Para pekerja belum mampu memanfaatkan kesempatan yang diberikan oleh perusahaan untuk menyampaikan pendapat, ide yang terkait dengan pekerjaannya.

Kata kunci: Learning organizations, perusahaan kecil-menengah.

\section{Pendahuluan}

$\mathrm{M}$ enghadapi tantangan ke depan, organisasi bisnis perlu meningkatkan kemampuannya agar memiliki daya bersaing, yang dalam konteks ini bermakna kemampuan untuk melakukan perubahan. Organisasi yang dapat berubah adalah organisasi yang memfasilitasi pembelajaran di lingkungan kerjanya. Memasuki era pengetahuan dan teknologi saat ini, organisasi bisnis menghadapi peningkatan kompleksitas dan ketidakpastian disebabkan perubahan lingkungan bisnis dan teknologi yang cepat. Agar tetap mampu bertahan (survive) dan tumbuh dalam lingkungan baru yang penuh tantangan memaksa setiap organisasi untuk memperbarui strategi bahwa organisasi harus beradaptasi dan terus melakukan pembelajaran (Learning Organization). Era perubahan juga menuntut organisasi lebih fleksibel dan tanggap (responsiveness) terhadap lingkungan yang berubah. Fleksibilitas organisasi memerlukan adanya kerja sama tim dan pelimpahan kekuasaan yang lebih besar kepada karyawan. Keunggulan sebuah organisasi dalam menghadapi ketatnya persaingan bisnis sangat tergantung pada individu yang berada di dalamnya. Pekerja maupun pimpinan organisasi dituntut memiliki kecepatan, kemampuan daya tanggap, kelincahan, kemampuan pembelajaran dan kompeten melalui pengetahuan, ketrampilan, dan kemampuan yang berhubungan dengan pekerjaan (Ulrich, 1998). 
UNISIA, Vol. XXXII No. 72 Desember 2009

Pengelola organisasi dituntut untuk terus berpikir bagaimana membangun dan mempertahankan keunggulan kompetitif yang berkelanjutan dalam persaingan. Perubahan lingkungan yang cepat menuntut setiap organisasi untuk cepat tanggap dan beradaptasi dengan perubahan.

Pitts (1996) mengemukakan, bahwa keunggulan kompetitif organisasi dapat dibangun dan dipertahankan melalui strategi mengelola perubahan yaitu dengan membangun Learning Organizations. Proses Learning Organizations melibatkan adanya pembelajaran individu agar mengadakan perubahan berpikir dari organisasi tradisional dengan mengembangkan kecakapannya melalui organisasi pembelajaran dengan berpikir kritis dan kreatif. Ketrampilan berpikir kritis dan kreatif merupakan nilai-nilai yang melekat di dalam mengembangkan organisasi. Perubahan ini memerlukan pembelajaran diantaranya berupa ketrampilan baru dan mengembangkan sumber-sumber keunggulan kompetitif yang baru. Dengan demikian untuk survive perusahaan tidak bisa bersandar pada sumber-sumber keunggulan kompetitif yang ada, namun mereka dituntut harus bisa belajar teknologi baru, pasar baru, dan cara pengelolaan yang baru (Pitts, 1996). Menghadapi tantangan ke depan, hanya organisasi yang mampu berubah dan belajar keterampilan baru secara berkelanjutan akan menjadi satusatunya sumber keunggulan kompetitif bagi perusahaan. Perusahaan yang menjadikannya suatu organisasi pembelajaran, memandang bahwa perubahan adalah sebagai peluang positif untuk berkreasi dan belajar sumber-sumber keunggulan kompetitif baru.

Sesuai tuntutan zaman yang sering diliputi perubahan, perusahaan-perusahaan di Indonesia idealnya mengarahkan pada suasana mentradisikan organisasi pembelajaran. Konsep pengembangan SDM harus berlangsung terus menerus selama individu bekerja di perusahaan. Dalam konsep pengembangan SDM ini dilakukan melalui konsep dinamika kelompok dimana di dalamnya berlangsung diskusi terhadap permasalahan yang muncul maupun pencapaian tujuan yang ditetapkan bersama dalam kelompok.

Kondisi bisnis di lapangan menunjukkan bahwa industry kecil mebel rotan di Trangsan, umumnya berproduksi untuk memenuhi kebutuhan perusahaan menengah dan besar yang berorientasi ekspor. Perusahaan menengah dan perusa-haan besar lebih memfokuskan pada pekerjaan finishing produk, memasarkan produk ke luar negeri dan menjalin hubungan baik dengan pengrajin lokal. Melalui cara sub kontrak, pelaku usaha di lingkungan perusahaan menengah dan besar memberi order kepada para pengesub dengan desain yang sudah ditentukan. Bentuk kerjasama lain yang dilakukan perusahaan menengah dan besar adalah menerima sampel produk dari kalangan pengesub untuk dipasarkan dengan harga yang telah disepakati.

Berdasarkan laporan startistik industri kecil Kabupaten Sukoharjo tahun 2008, di Desa Trangsan terdapat lebih kurang 150 perusahaan. Ketika menerima order dari perusahaan menengah-besar, para pengrajin yang bertindak sebagai pengesub tidak hanya menggunakan pekerjanya sendiri tetapi juga melibatkan para pekerja anyaman di luar perusahaan yaitu dengan mendistribusikan pekerjaan penganyaman kepada pengrajin di sekitar lokasi usahanya.

Berdasarkan aktivitas proses produksi yang dilakukan perusahaan yaitu dengan cara dikerjakan sendiri sejak bahan baku hingga finishing dan di subkontrakkan kepada pengesub. Sistem partner yang dilakukan perusahaan dengan para pengesub 
Learning Organizations Di Lingkungan Perusahaan Kecil- Menengah...; Sri Walyoto

beragam. Ketersediaan pekerja pada industri mebel rotan tidak banyak mengalami masalah karena tenaga kerja sebagian besar di pasok oleh penduduk setempat, namun banyak pula pekerja berasal dari luar daerah.

Selama interview dengan para pekerja di lapangan, sebagian besar tidak menghadapi kendala proses pengerjaan, tetapi jika ada pesanan dengan desain baru mereka menghadapi kesulitan dan memerlukan waktu cukup lama sehingga waktu pengerjaan menjadi tidak efisien. Pemasaran oleh sebagian besar perusahaan adalah berorientasi pasar ekspor (95\%) dan selebihnya $(5 \%)$ orientasi pasar lokal. Beberapa Negara yang menjadi tujuan ekspor antara lain Australia, Jerman, Belanda, Mexico, Amerika, Eropa, Malaysia, Inggris, Filipina, Jepang, Korea, Argentina, Perancis, Thailand, Spanyol, Italia, Belgia, Argentina, Taiwan, Kanada. Promosi yang dilakukan perusahaan, sebagian besar dilakukan dengan cara mendatangi langsung pedagang besar, dan selebihnya melalui pameran dagang, brosur, iklan, internet. Para pelanggan memiliki peran penting sebagai sumber perancangan desain dan memperkaya keragaman desain bagi perusahaan, hal ini karena desain produk pada umumnya berasal dari pelanggan. Rancangan desain juga bersumber dari pihak pengesub/pengrajin lokal dan dari para pekerja.

Berdasarkan fenomena bisnis itulah yang melatar belakangi studi ini untuk dilakukan kajian terkait dengan learning organizations di lingkungan perusahaan kecil dan menengah. Lingkup kajian dalam studi ini mengenai praktek terhadap piranti-piranti pembelajaran di lingkungan perusahaan kecil dan menengah di sentra industri kecil mebel rotan desa Trangsan, Gatak, Sukoharjo. Sejauhmana organisasi pembelajaran telah dibangun di kalangan perusahaan tersebut. Kajian ini cukup beralasan mengingat sebagai perusahaan yang memproduksi mebel, produk yang dihasilkan lebih banyak mengandung unsur seni yang tentunya memerlukan daya kreativitas agar tetap kompetitif.

Konsep organisasi belajar dewasa ini telah menjadi core pengembangan SDM dalam organisasi. Untuk menghadapi perubahan dan beradaptasi diperlukan strategi mengelola perubahan dan ini dapat dilakukan melalui pengelolaan learning organization (LO).

Model LO yang dikembangkan Pitts (1996) digunakan dasar kajian atas praktik learning organization di lingkungan industri kecil-menengah, di sentra industri mebel rotan di Trangsan sebagaimana ditunjukkan gambar 1. Pitts (1996) mengembangkan model Learning Organization, meliputi enam karakteristik Learning Organization. Diantara enam karakteristik dalam model, karakteristik continual training tidak terdapat dalam praktik organisasi di perusahaan kecil-menengah.

Berangkat dari latar belakang dan model di atas, masalah penelitian dirumuskan sebagai berikut:

1. Bagaimana praktik pengelolaan Learning Organization di sentra industri kecil mebel rotan Trangsan

2. Apakah karakteristik Learning Organization memiliki bobot prioritas yang berbeda berdasarkan penilaian pekerja

3. Apakah karakteristik Learning Organization memiliki bobot prioritas yang berbeda berdasarkan penilaian pengesub

4. Apakah ada perbedaan penilaian pekerja dan pengesub terhadap perusahaan kecil dan menengah dalam praktik pengelolaan Learning Organization. 
UNISIA, Vol. XXXII No. 72 Desember 2009

\section{Gambar 1 Pengelolaan Learning Organization}

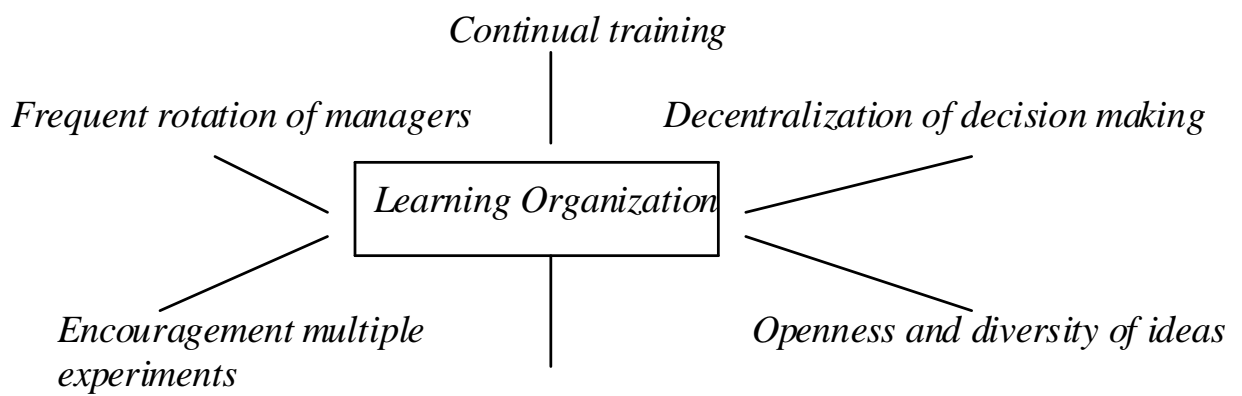

High tolerance of failure

Sumber: Robert A.Pitts dalam Strategic Management: Building and Sustaining Competitive Advantage, 1996:346

5. Apakah terdapat perbedaan bobot prioritas karakteristik Learning Organization di perusahaan kecil dan menengah menurut penilaian responden

\section{Kajian Pustaka dan Hipotesis}

Menurut Senge (1990), orang yang ingin bersaing dalam lingkungan bisnis, harus menjadikan organisasinya "organisasi belajar" dengan terus menerus beradaptasi terhadap lingkungan. Kemampuan setiap perusahaan dalam mengantisipasi dan beradaptasi atas setiap perubahan sangat menentukan kelangsungan hidupnya. Kemampuan mengantisipasi perubahan ini tergantung pada kemampuan kreativitas dan inovasi para anggota organisasi. Menurut Marquardt (dalam Shaffar, 2001) bahwa organisasi akan dapat menjadi "organisasi belajar" hanya dengan membelajarkan individu-individu di dalamnya dengan memberdayakan aspek pembelajaran, organisasi, manusia, pengetahuan dan teknologi. Sebagai organisasi yang belajar (LO) hendaknya selalu memberikan kesempatan kepada para pekerja agar selalu dapat memperbaiki diri untuk meraih sukses. Melalui pembelajaran individu dapat melakukan segala sesuatu yang sebelumnya tidak pernah dilakukan. Untuk menciptakan individu pembelajar, adalah dengan memberi kesempatan luas kepada karyawan untuk meng-Up Date pengetahuan. Mewujudkan organisasi yang mampu belajar dan berkembang dibutuhkan sumber daya intangible yang sangat penting kontribusinya yaitu sumber daya manusia. SDM ditentukan oleh pengetahuan pekerja, kemampuan intelektual, ketrampilan, kompetensi dan pikiran (intangible assets). Apabila intangible assets ini dikembangkan terus menerus maka akan menjadi tiang organisasi dalam membangun dan mengelola learning organization (LO) sehingga memiliki keunggulan kompetitif.

Di Indonesia, Toyota Motor Corporation merupakan salah satu organisasi yang mampu memaksimalkan kemampuan sumber daya intangible assets. Hasil riset tentang "10 kompetensi terpenting dalam abad ke-21" yang dilakukan di organisasi di 16 negara, menempatkan inovasi sebagai kompetensi kedua terpenting setelah orientasi pelanggan. Sejalan dengan pemikiran Peter Drucker, yang mengatakan bahwa "bagi perusahaan mapan, mensyaratkan adanya inovasi dan yang tidak 
Learning Organizations Di Lingkungan Perusahaan Kecil- Menengah...; Sri Walyoto

mampu inovasi akan menghadapi nasib kemerosotan dan pemunahan". Pemikiran Peter Drucker ini nampaknya menjadi pijakan pengembangan bisnis pada Perusahaan Toyota Motor, yang merupakan perusahaan raksasa mobil dunia, sejak tahun 1961 telah mengimplementasikan 20 juta Inovasi (ide), dan implementasi Inovasi ini karena didukung system Konowledge Management, yakni proses yang dilakukan untuk menciptakan "nilai" dengan cara meningkatkan modal Intangible Assets yang dimiliki organisasinya (Warta Ekonomi, 2004).

Arvan Pradiansyah seorang konsultan SDM Franklin Covey Indonesia mengatakan, bahwa inovasi merupakan hasil dari budaya Learning Organization yang dilakukan organisasi. Sydney Brenner, mengatakan bahwa inovasi adalah suatu spekulasi, bahwa kerja akan membawa kesuksesan melalui suatu kegagalan. Berkaitan dengan pernyataan Sydney Brenner, ada hal yang menarik, yaitu adanya kejadian di perusahaan IBM (SWA, 2001), dimana seorang karyawan melakukan kesalahan sehingga merugikan perusahaan hingga US\$ 10 juta. Karyawan ini bermaksud mengundurkan diri karena merasa berbuat kesalahan namun oleh pimpinan IBM ditolak, dengan alasan perusahaan telah mengeluarkan biaya cukup besar untuk pelatihan. Perilaku karyawan tersebut menggambarkan bahwa kesalahan yang sempat dilakukannya dianggap sebagai investasi. Kesalahan ini dipandang sebagai bentuk pembelajaran, dan juga percobaan atau pengalaman. Ini adalah representasi sebuah organisasi inovatif, yaitu organisasi yang belajar hidup dengan resiko, termasuk berbuat kesalahan. Untuk mampu berkembang menjadi LO, sebuah organisasi memerlukan seperangkat karakteristik khusus, yaitu karakteristikkarakteristik Learning Organization (LO).
Sudharatna dan Lie (2004) dalam studi yang dilakukan tentang karakteristikkarakteristik LO hubungannya dengan kesiapan untuk berubah, menunjukkan temuan ada korelasi positif antara karakteristik LO yang meliputi nilai kultur, pemberdayaan dan komitmen kepemimpinan, komunikasi, transfer pengetahuan, karakteristik karyawan dan peningkatan kualitas kinerja dengan kesiapan organisasi untuk berubah. Interpretasi dari hasil studi ini bahwa suatu organisasi yang memiliki karakteristik LOyang kuat maka organisasi juga memiliki kesiapan yang tinggi untuk berubah.

Tuntutan organisasi untuk mampu tetap bertahan dalam situasi lingkungan yang cepat berubah, diperlukan kesiapan untuk menghadapinya dengan cara mengelola perubahan itu sendiri. Piits (1996: 346) mengembangkan model praktik pengelolaan Learning Organization melalui 6 kunci karakteristik yang potensial menjadikan sebuah organisasi sebagai organisasi yang belajar, diantaranya: (1) Rotasi manajer; (2) Training berkelanjutan; (3) Desentralisasi pengambilan keputusan; (4) Mendorong eksperimen; (5) Toleransi terhadap kesalahan/kegagalan dan (6) Keterbukaan dan keragaman ide.

\section{Hipotesis:}

1. Karakteristik Learning Organization memiliki bobot prioritas yang berbeda berdasarkan penilaian pekerja

2. Karakteristik Learning Organization memiliki bobot prioritas yang berbeda berdasarkan penilaian pengesub

3. Terdapat perbedaan bobot prioritas karakteristik Learning Organization di perusahaan kecil dan menengah menurut penilaian responden

4. Terdapat perbedaan penilaian pekerja dan pengesub terhadap perusahaan 
UNISIA, Vol. XXXII No. 72 Desember 2009

kecil dan menengah dalam praktik pengelolaan Learning Organization

\section{Metode Penelitian}

Penelitian ini merupakan penelitian lapangan yaitu untuk melakukan Exploratory mengenai praktek pengelolaan learning organization di kalangan perusahaan kecil menengah yang berlokasi di sentra industri kecil mebel rotan di Trangsan Sukoharjo.

\section{Populasi, Teknik Sampling dan Sampel}

Populasi dalam penelitian ini adalah perusahaan-perusahaan yang berlokasi di sentra industry kecil mebel rotan di desa Trangsan, Gatak, Sukoharjo. Teknik pengambilan sampel dengan metode purposive sampling. Tiga jenis sampel dalam penelitian, yakni pengusaha/pemilik perusahaan, pekerja dan pengesub. Dari 60 kuesioner yang disebar ke responden pengusaha/pimpinan perusahaan, yang dapat dianalisis 50 responden. Dari 40 kuesioner yang disebar ke responden pekerja dan pengesub, yang dapat dianalisi sebanyak 35 responden.

\section{Metode Pengumpulan Data}

Penelitian ini menggunakan data primer, yang dirancang untuk tiga kelompok responden yakni:

1. Kuesioner responden pimpinan perusahaan (produsen).

Perancangan kuesioner ini diawali dengan studi pendahuluan untuk mendapatkan kesesuaian data variabel LO berdasarkan kriteria-kriteria LO yang dikembangkan oleh Pitts (1996) dengan iklim pembelajaran yang ada di lingkungan perusahaan. Pertanyaan yang dikembangkan dalam kuesioner terdapat 40 item pertanyaan.
2. Kuesioner responden pekerja dan responden pengesub.

Kuesioner dirancang dengan format matrik perbandingan berpasangan, untuk mendapatkan jawaban penilaian responden, dengan cara membandingkan antar karakteristik/atribut. Data karakteristik LO berupa data perbandingan berpasangan dengan skala $1-9$, yang dipandu langsung oleh interviewer dengan durasi waktu rata-rata antara 15-25 menit/ responden.

\section{Uji Validitas, Reliabilitas dan Konsistensi}

Pengujian ini dimaksudkan untuk memenuhi kriteria kuesioner yang baik. Pengujian validitas dan reliabilitas dilakukan dengan metode One Shot. Kriteria uji validitas secara rule of tumb adalah 0,30 . Pengujian reliabilitas instrumen diketahui malalui koefisien Cronbach's Alpha. Suatu instrumen dikatakan reliable apabila memiliki nilai koefisien Cronbach's Alpha e" 0,50 (Nunnaly, 1967:Hair et al., 1998).

Pengujian akurasi matrik jawaban responden (pekerja dan pengesub) menggunakan Consistency Ratio (CR). Tingkat konsistensi menunjukkan tingkat akurasi suatu pendapat terhadap elemen-elemen pada suatu tingkat hirarki. Pengulangan wawancara atau revisi pendapat dapat dilakukan pada sejumlah responden yang sama apabila derajat inkonsistensi besar yang dapat dilihat dari nilai CR pendapat yang cukup tinggi ( $>0.10$ ). Saaty (1988) membuktikan bahwa Indek konsistensi dari orde matrik dapat diperoleh dengan rumus:

$$
\text { ë maksimum - } \mathrm{n}
$$

$$
\begin{aligned}
& \begin{array}{l}
\text { Consistency Index }=\frac{}{(\text { Saaty, 1988). }} \\
\text { dimana: }
\end{array} \\
& \text { ë maksimum = nilai Eigen ,aksimum dari }
\end{aligned}
$$


Learning Organizations Di Lingkungan Perusahaan Kecil- Menengah...; Sri Walyoto

matriks berordo $n$

$\mathrm{n}=$ jumlah faktor/atribut/elemen yang dibandingkan

Nilai eigen maksimum (ë maksimum) = " (jumlah kolom pada matriks $\mathrm{x}$ Eigenvector Utama).

Menurut Saaty (1988), batas inkonsistensi jawaban responden dapat diukur melalui Rasio Konsistensi, yaitu perbandingan indek konsistensi $(\mathrm{Cl})$ dengan nilai Random Consistency atau indeks acak (tabel 1). sehingga dapat meningkatkan kompetensinya. Variabel LO diukur dengan mengembangkan item pertanyaan dalam kuesioner. Terdapat 5 karakteristik LO dalam penelitian ini yakni continual training of personnel, decentralization of decision making, encouragement of multiple experiments, high tolerance for failure dan openness and diversity of ideas.

Instrumen untuk mengukur variabel LO menggunakan skala interval dan setiap pertanyaan disediakan 4 pilihan jawaban

Tabel 1 Nilai Random Konsistensi atau nilai Random Index (RI)

\begin{tabular}{|l|c|c|c|c|c|c|c|c|c|c|}
\hline $\begin{array}{l}\text { Size of matrix } \\
\text { atau n }\end{array}$ & 1 & 2 & 3 & 4 & 5 & 6 & 7 & 8 & 9 & 10 \\
\hline $\begin{array}{l}\text { Random } \\
\text { Consistency (RI) }\end{array}$ & 0 & 0 & 0.58 & 0.9 & 1.12 & 1.24 & 1.32 & 1.41 & 1.45 & 1.49 \\
\hline
\end{tabular}

Sumber: Saaty (1988)

Derajat $C R$ diformulasikan:

C.I

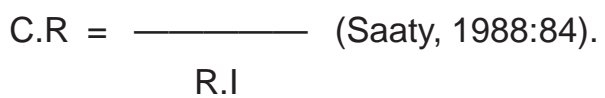

Apabila C.R d" 0.10 maka inkonsistensi pendapat dapat diterima. Nilai CR dicari untuk setiap level dalam AHP. Eigenvector Utama maupun nilai CR dilakukan pada setiap level. Dalam studi ini terdapat 3 level, yaitu tujuan, kriteria dan alternatif. Pada level kriteria dan alternatif masing-masing disusun kuesioner dan dilakukan perhitungan $\mathrm{CR}$.

\section{Operasionalisasi Variabel}

Learning Organization dioperasionalkan sebagai organisasi yang memberikan kesempatan dan mendorong setiap individu dalam organisasi untuk terus belajar dan meningkatkan kapasitas dirinya. Melalui belajar, individu akan memperoleh pengetahuan, pemahaman dan keterampilan yaitu selalu, sering, kadang-kadang dan tak pernah. Masing-masing jawaban secara berurutan diberi skor 4, 3, 2, 1. Berdasarkan item-item pertanyaan yang telah memenuhi uji validitas dan reliabilitas digunakan dasar penyusunan kuesioner dalam format matrik perbandingan berpasangan. Terdapat 8 faktor LO yang ditujukan pada responden pekerja dan 7 faktor LO pada responden pengesub. Jumlah pertanyaan untuk pekerja $=n(n-1) / 2$ (karena saling berkebalikan dan diagonalnya selalu bernilai 1 ), yaitu $8(8-1) / 2=28$ pertanyaan. Jumlah pertanyaan untuk responden pengesub ada $7(7-1) / 2=21$ pertanyaan. Pengukuran variabel yang dimaksud ditunjukkan pada tabel 2.

Continual training: Menghadapi \& beradaptasi terhadap perubahan, diperlukan pembelajaran, melalui pelatihan berkelanjutan. Komitmen terhadap pengembangan SDM mendorong lahirnya ide-ide barukomit- 
UNISIA, Vol. XXXII No. 72 Desember 2009

men pimpinan pada pengembangan SDM- Decentralization of decision making: pendekatan dalam belajar Desentralisasi pengambilan keputusan,

Tabel 2 Validitas Konstruksi - Learning Organization

Tabel 3 Atribut-atribut Learning Organizations untuk penyusunan kuesioner AHP

\begin{tabular}{|l|l|}
\hline Płkerja & \\
\hline & \\
\hline
\end{tabular}


Learning Organizations Di Lingkungan Perusahaan Kecil- Menengah...; Sri Walyoto

Tabel 4 Karakteristik learning organizations pada dua kelompok responden

\begin{tabular}{|l|l|l|}
\hline \multicolumn{1}{|c|}{ Indikator } & $\begin{array}{l}\text { Faktor/Atribut } \\
\text { Pekerja }\end{array}$ & $\begin{array}{l}\text { Faktor/Atribut } \\
\text { Pengesub }\end{array}$ \\
\hline Continual Training & $\mathrm{A}-\mathrm{B}$ & $\mathrm{A}$ \\
\hline Decentralizations of decision making & $\mathrm{C}$ & $\mathrm{B}$ \\
\hline Encouragement multiple experiments & $\mathrm{D}-\mathrm{E}$ & $\mathrm{C}-\mathrm{D}$ \\
\hline High tolerance offailure & $\mathrm{F}$ & $\mathrm{E}$ \\
\hline Openness of ideas & $\mathrm{G}-\mathrm{H}$ & $\mathrm{F}-\mathrm{G}$ \\
\hline
\end{tabular}

Tabel 5 Skala Fundamental - Skala Banding Secara Berpasangan

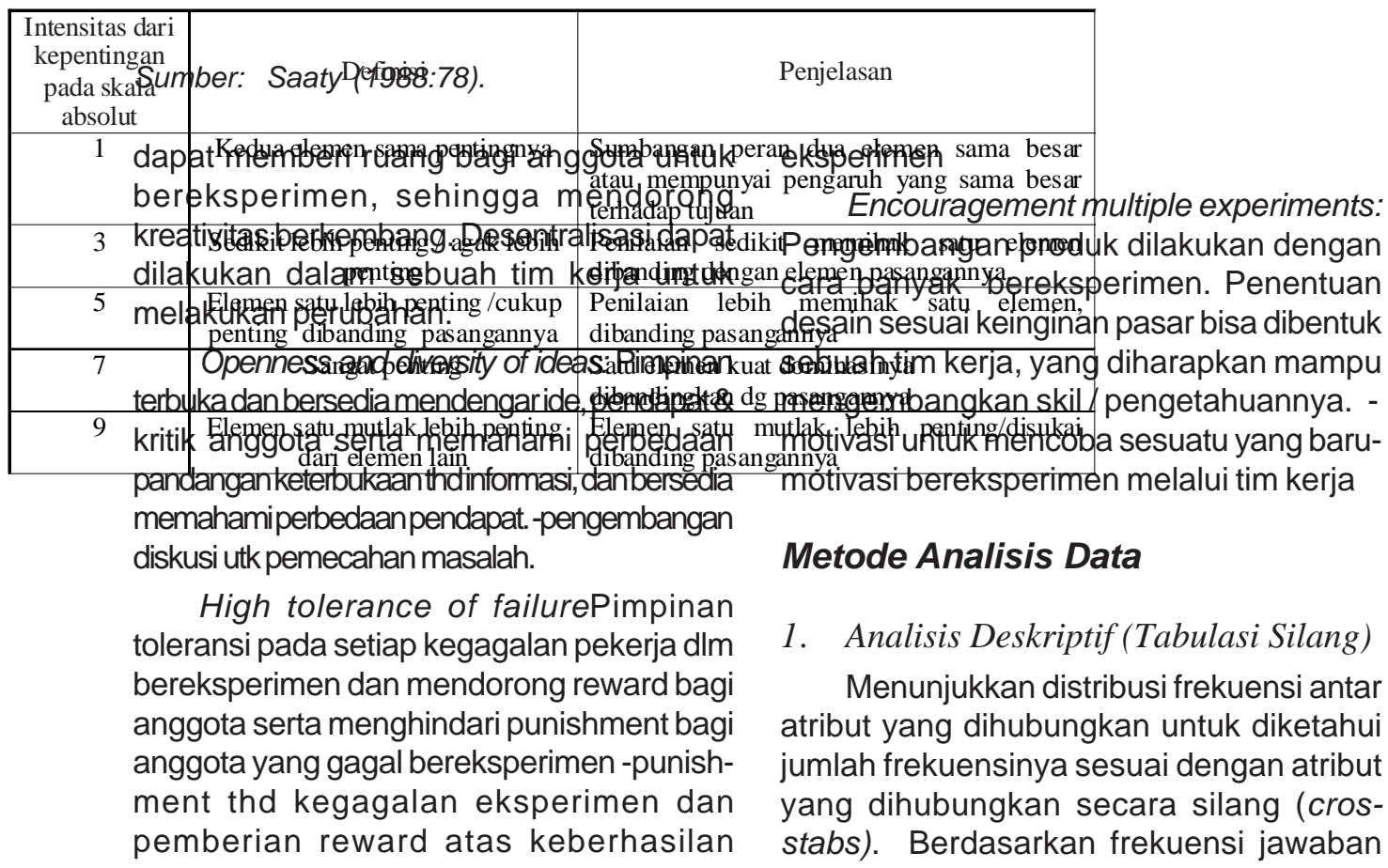


UNISIA, Vol. XXXII No. 72 Desember 2009

responden dapat dilakukan analisis skoring setiap jawaban dari responden.

\section{Analitical Hierarchy Process}

Metode AHP untuk menganalisis nilai kepentingan atribut-atribut learning organizations yang berpengaruh dalam membangun suatu organisasi yang belajar.

Analisis data dengan AHP diawali dengan:

2.1. Penyusunan struktur hirarki

2.2. Perbandingan berpasangan; teknik ini berdasarkan pendapat responden

2.3. Matrik pendapat individu dengan formulasi sebagai berikut:

C1, C2 ......Cn adalah set elemen pada satu tingkat dalam hirarki. Kuantifikasi pendapat dari hasil perbandingan berpasangan membentuk matriks $n \times n$. Nilai $a_{\text {i }}$ merupakan nilai matrik pendapat hasil perbandingan yang mencerminkan nilai kepentingan $\mathrm{C}_{\mathrm{i}}$ terhadap $\mathrm{C}_{\mathrm{j}}$.

2.4. Matrik pendapat gabungan; merupakan matrik baru yang elemen-elemennya berasal dari rata-rata geometric elemen matriks pendapat individu

2.5. Nilai pengukuran konsistensi; adalah untuk menghitung konsistensi jawaban responden

2.6. Penentuan prioritas pengaruh setiap elemen pada tingkat hirarki keputusan tertentu terhadap sasaran utama.

\section{Analisis Varian}

Analisis varian untuk menguji hipotesis pertama, kedua dan ketiga.

\section{Independent Sample T-Test}

Uji t digunakan untuk menguji hipotesis keempat yakni untuk uji perbedaan rata-rata bobot alternatif atau Overall Priority Ranking antara perusahaan kecil dan menengah (yang menunjukkan perbedaan penilaian pekerja dan pengesub terhadap perusahaan kecil-menengah dalam praktik pengelolaan

LO).

C1

\section{Hasil Penelitian dan Pembahasan}

\section{A. Uji Validitas, Reliabilitas dan Konsistensi Rasio}

Hasil uji validitas dan uji reliabilitas kuesioner, menghasilkan 30 item pertanyaan valid dan reliable, diindikasikan oleh koefisien $r>0.30$ dan koefisien Cronbach's Alpha sebesar 0.922. Hasil uji konsistensi jawaban responden pekerja dan pengesub, menunjukkan, bahwa Consistency Ratio (CR) terhadap jawaban semua responden pekerja dan pengesub adalah konsisten diindikasikan oleh angka C.R $<0,10$. 
Learning Organizations Di Lingkungan Perusahaan Kecil- Menengah...; Sri Walyoto

\section{B. Tabulasi Silang}

Hasil analisis dengan tabulasi silang secara umum menunjukkan, karakteristik Continual Training for personnal tergolong kategori rendah dalam mendukung terbentuknya sebuah organisasi yang mampu belajar. Decentralization of decision making , openness and diversity of ideas, high tolerance of failure, dan encouragement multiple experiments, cukup mendukung upaya membangun Learning Organization.

\section{Hasil Pengujian Hipotesis}

\section{Pengujian Hipotesis 1:}

Hipotesis pertama dalam penelitian ini untuk menguji apakah atribut-atribut/ karakteristik Learning Organization memiliki bobot prioritas berbeda berdasarkan penilaian pekerja

Hasil analisis dengan uji Anova satu factor (one way Anova) menunjukkan bahwa nilaij statistic Brown-Forsythe 14.897 dengan probabilitas nol dan nillai státiśtic...

C1 Welch 25.169 dengan probabilitas nol.

C1 Keslmpulannya Ho ditolak dân Hi diterima,...

$\mathrm{C} 2$

....

C3
16,682 probabilitas nol, dan nilai statistic Welch 10,607 dengan probabilitas nol. Kesimpulannya Ho ditolak dan Hi diterima, artinya ada perbedaan sangat signifikan bobot prioritas atribut-atribut/karakteristik LO berdasarkan penilaian pengesub. Hasil temuan empiris ini diinterpretasikan bahwa atribut LO yang terdiri tujuh atribut memiliki pengaruh atau kontribusi berbeda bagi pembelajaran individu.

\section{Pengujian Hipotesis 3:}

Hipotesis ketiga menguji perbedaan bobot prioritas atribut/karakteristik Learning Organization di perusahaan kecil-menengah berdasarkan penilaian responden.

Hasil uji perbedaan bobot prioritas atribut LO di perusahaan kecil:

Hasil analisis menunjukkan nilai $\mathrm{F}=$ 10.220 dengan taraf signifikansi nol. Kesimpulannya, Ho ditolak dan $\mathrm{H}_{1}$ diterima. Berdasarkan hasil temuan tersebut membuktikan bahwa terdapat perbedaan bobot prioritiss sangat nyata di perusahaan kecil menurut penilaian pekerja. Artinya bahwa atribut LO memiliki pengaruh atau kontribusi bërbedla bagi pembelajaran individu dalam artinya $_{1}$ gda perbedaan sangat signifikan.... miëwüudkan organisasi yang mampu bobọt.prioritas atribut-atribut/karakteristik .L..... betajar. berdasarkan penilaian pekerja1 Hassil temuan........ empiris ini diinterpretasikan bahwa atribut LO yang terdiri delapan atribut memiliki pengaruh atau kontribusi berbeda bagi pembelajaran individu.

\section{Pengujian Hipotesis 2:}

Hipotesis kedua dalam penelitian ini untuk menguji apakah atribut-atribut Learning Organization memiliki bobot prioritas berbeda berdasarkan penilaian pengesub.

Hasil analisis dengan uji Anova satu factor (one way Anova) membuktikan bahwa nilai statistic Brown-Forsythe sebesar
Hasil pengujian yang sama berdasarkan penilaian pengesub menunjukkan, nilai statistic Welch 17.941 dengan angka signifikansi nol, dan nilai statistic BrownForsythe 13.677 dengan taraf signifikansi nol. Kesimpulannya, Ho ditolak dan menerima $\mathrm{H}_{1}$. Hal ini berarti ada perbedaan sangat nyata bobot prioritas atribut $L O$ di perusahaan kecil berdasarkan penilaian pengesub, yang berarti factor-faktor LO memiliki peran atau kontribusi tidak sama bagi pembelajaran individu.

Hasil uji perbedaan bobot prioritas atribut LO di perusahaan menengah: 
UNISIA, Vol. XXXII No. 72 Desember 2009

Hasil analisis dengan uji $F$ (Anova) menunjukkan nilai $F=10.241$ dengan taraf signifikansi nol. Kesimpulannya, Ho ditolak dan $\mathrm{H}_{1}$ diterima. Temuan tersebut membuktikan bahwa terdapat perbedaan bobot prioritas sangat nyata di perusahaan menengah menurut penilaian pekerja. Artinya bahwa atribut LO memiliki pengaruh atau kontribusi berbeda bagi pembelajaran individu.

Hasil penilaian pengesub menunjukkan temuan nilai statistic Welch 17.959, dengan taraf signifikansi nol, dan nilai statistic Brown-Forsythe sebesar 13.478 dengan taraf signifikansi nol. Hasil temuan ini menunjukkan bahwa $\mathrm{Ho}$ ditolak dan $\mathrm{H}_{1}$ diterima, berarti ada perbedaan sangat nyata bobot peioritas atribut $L O$ di perusahaan menengah. Faktor-faktor $L O$ di perusahaan menengah memiliki peran berbeda untuk pembelajaran individu.

\section{Pengujian Hipotesis 4:}

Hipotesis keempat menguji perbedaan penilaian pekerja dan pengesub terhadap perusahaan kecil dan menengah dalam praktik pengelolaan Learning Organization

Berdasarkan hasil uji t terhadap bobot alternatif secara keseluruhan, membuktikan bahwa ada perbedaan penilaian (bobot prioritas alternative) sangat nyata antara dua kelompok perusahaan dalam praktik pengelolaan LO. Hasil uji t menunjukkan nilai - 3,132 dan signifikansi 0,003 sehingga disimpulkan Ho ditolak dan menerima $\mathrm{Hi}$. Artinya ada perbedaan penilaian kelompok responden pekerja. Berdasarkan hasil penilaian pekerja, bahwa kelompok perusahaan kecil kurang baik atau dinilai lemah (skor 0,5440) dalam praktik pengelolaan LO. Hasil penilaian pengesub menunjukkan nilai $\mathrm{t}=2,721$ dan signifikansi 0,008 . Kesimpulannya, Ho ditolak dan menerima Hi. Ini artinya ada perbedaan penilaian (perbedaan rata-rata bobot alternative) berdasarkan penilaian kelompok responden pengesub. Berdasarkan penilaiannya, bahwa perusahaan kecil lebih baik dalam praktik pengelolaan LO $(0,5379)$ sedangkan perusahaan menengah dinilai kurang baik/ lemah dalam praktik pengelolaan LO $(0,4609)$.

\section{Analitical Hierarchy Process}

Berdasarkan analisis overall priority ranking atau bobot prioritas alternative telah membuktikan bahwa praktik pengelolaan LO di perusahaan menengah, menurut penilaian pekerja menyatakan bahwa di perusahaan menengah adalah lebih baik (bobot prioritas alternatif sebesar 0,5440).

Sedangkan menurut penilaian pengesub, seperti ditunjukkan pada gambar 4 , menunjukkan kecenderungan pendapat bahwa praktek LO di lingkungan perusahaan kecil adalah lebih baik dibandingkan dengan perusahaan menengah. Penilaian terhadap praktek $L O$ di perusahaan kecil ini ditunjukkan oleh rata-rata bobot prioritas alternatif sebesar 0.5379 sementara perusahaan menengah 0.4610 .

Hasil temuan empiris berdasarkan analisis penilaian antar atribut dan penilaian antar alternative tersebut di atas, maka nilai bobot prioritas atribut dan nilai bobot prioritas alternative, apabila disatukan dalam sebuah model struktur hirarkhi (AHP) tampak pada gambar 4 yang merupakan penilaian pekerja dan gambar 5 menunjukkan penilaian pengesub.

\section{Penutup}

\section{Kesimpulan}

1) Organisasi belajar (LO) di lingkungan perusahaan kecil-menengah di sentra industri kecil mebel rotan di Tangsan 
Learning Organizations Di Lingkungan Perusahaan Kecil- Menengah...; Sri Walyoto

Gambar 2 Diagram bobot priritas Alternatif - pendapat pekerja

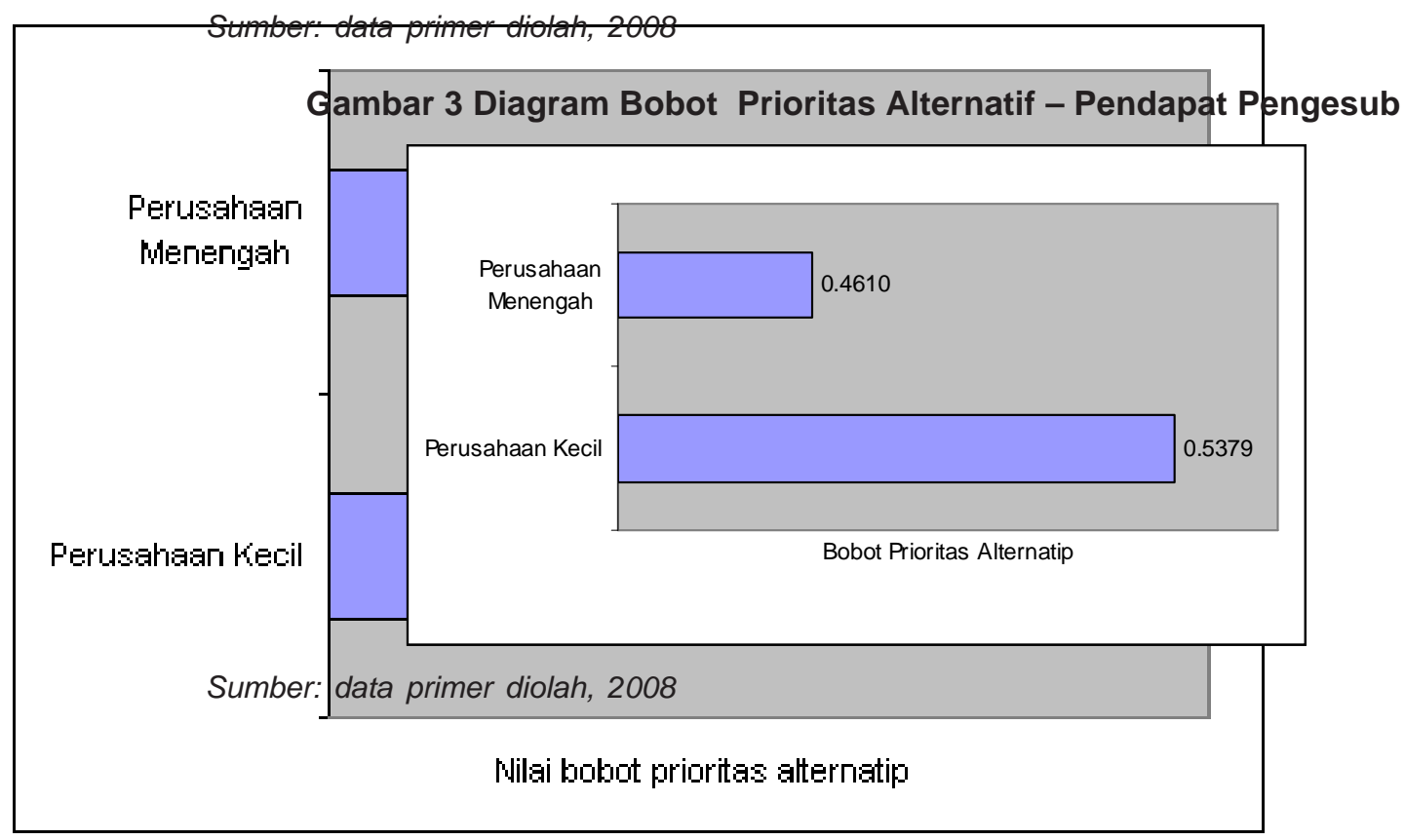

